First Peoples Child \& Family Review

An Interdisciplinary Journal Honouring the Voices, Perspectives, and Knowledges of
First Peoples through Research, Critical Analyses, Stories, Standpoints and Media

Reviews

\title{
Editorial: Gathering, Sharing and Documenting the Wisdom Within and Across our Communities and Academic Circles
}

\section{Jeannine Carriere}

Volume 5, Number 1, 2010

URI: https://id.erudit.org/iderudit/1069055ar

DOI: https://doi.org/10.7202/1069055ar

See table of contents

Publisher(s)

First Nations Child and Family Caring Society of Canada

ISSN

1708-489X (print)

2293-6610 (digital)

Explore this journal

Cite this document

Carriere, J. (2010). Editorial: Gathering, Sharing and Documenting the Wisdom

Within and Across our Communities and Academic Circles. First Peoples Child

\& Family Review, 5(1), 5-7. https://doi.org/10.7202/1069055ar 
Trivest Peoples Choild \& wamilly Review

An Interdisciplinary Journal Honoring the Voices, Perspectives and Knowledges of First Peoples through Research, Critical Analyses, Stories, Standpoints and Media Reviews

Volume 5, Number 1, 2010, p. 5-7

\title{
Editorial:
}

\section{Gathering, Sharing and Documenting the Wisdom Within and Across our Communities and Academic Circles}

\author{
Jeannine Carriere
}

Writing this editorial is both an honour and a challenge for me cloaked in sadness. My sadness comes from our dedication of this issue to Roxanne Charlie who lost her life while we were preparing for this journal and after some of us had the honour to witness her story at our Gathering and Sharing Wisdom conference in Victoria, BC, October, 2009. How many more of our youth will we lose this year and how many voices will go unheard? Roxanne as our dedication states, we honour your life and thank you for the bright light you brought to us at our conference and in our lives. You are indeed an inspiration.

Our conference also opened with another inspirational speaker, Chief Wayne Christian who submitted his words of wisdom to our journal by reminding us that placing children at the center is our collective duty. Chief Christian revisited the impacts of the sixties scoop and how he and his community challenged the child welfare system through standing together and reclaiming jurisdiction and traditional child caring laws almost thirty years ago. Quoting several Indigenous authors in his article, Chief Christianson states that, "We must all reinvest in our children if the policy of the government was 'to kill the Indian child' then our policy is to 'bring back to life the Indian in the child.' He closes strongly by reminding us that if we believe that children are our future then "our future is now" in order to preserve the next seven generations. Well said.

The Indigenous Child Welfare Research Network at the University of Victoria was the coordinating body for the Gathering and Sharing Wisdom Conference mentioned earlier. Under the leadership of Jacquie Green, this network has provided a forum for many Indigenous practitioners, academics, students, community members and other interested parties to express their ideas on matters related to Indigenous child welfare. Throughout their article on the network, Jacquie
Green, Rebecca Taylor, Rakiva Larken, Margaret Brier and Trevor Good describe an innovative approach to training which engages members of Indigenous communities in learning what is research, how to conduct research and to demystify the role that research can play in our communities. The article also features the stories of young female and male warriors at the University of Victoria who are students with a high degree of personal commitment and vision for Indigenous communities. Their examples inspire our youth to reach to their highest potential and accomplish dreams for their families, communities and themselves.

We move from the voices of youth to the powerful voice of Elder Gordon Shawanda. Storytelling is powerful and it is at its most impactful through our Elders, our teachers. In this article I was riveted by Elder Shawanda's depiction of nature stories, the warmth of family and the description of his experiences in residential school. Early in the article as he describes a visit with an Elder as making him feel 'warm and cozy', I thought it was the same feeling that I experienced reading this article. It is an emotional and amazing testimonial of one of our Elder's life and in this article you will find a number of gems that make you smile or bring you to tears.

Gordon Shawanda leads the way into Dr, Maragaret Kovach's article on Indigenous research pedagogy and relational methods. Margaret reminds us of the importance of our personal location and how this interacts with methodology for Indigenous peoples. She cites a number of Indigenous scholars such as Shawn Wilson (2001) and Absolon and Willett (2004) and posits that "it is not the method per se, that is the determining characteristic of Indigenous methodologies, but rather the interplay (the relationship) between the method and paradigm and the extent to which the method itself is 


\section{Editorial}

congruent with an Indigenous worldview" (p.40). Margaret describes a 'conversational method' for Indigenous led research and provides examples in which she used this approach. In her conclusions she reminds the researcher of the importance of self care and to use a reflective process that centres the research paradigm and method in order to maintain the importance of relationship in research with Indigenous peoples.

The discussion on research using an Indigenous framework continues with the article by Naadi Todd Ormiston who cautions us on the outside interests of research such as what is conducted by government agencies. Todd reminds us of the power of oral histories and preserving our stories as a means to decolonization and maintaining the 'truths' of our communities. He states that "vital to Indigenous research is that it benefits our people, our communities and our Nations" (p.53).

Molly Wikham is a student in the Indigenous Governance program at the University of Victoria. In her article on youth custody, she encourages us to take a closer look at the injustices within the justice system for our youth. Margaret incorporates a strong critique of the current youth justice system and advocates for a decolonized approach to youth justice with "a blanket of cultural teachings and love" (p.60). Her passion for this topic is obvious and she concludes the article with an Indigenous framework for addressing the needs of Indigenous youth in the justice system.

Homelessness is predominant among our youth in urban centers across Canada. In 'Home and Native Land: Aboriginal Young Women and Homelessness', Lia Ruttan, Patti LaBoucane- Benson and Brenda Munro take us through the journey of young Aboriginal women on the streets of Edmonton, Alberta. The authors describe homelessness as 'enforced home loss' that is in dire need of resolution for the young women in their study who represent the youth of any city in Canada. The authors describe traditional community life before the massive urbanization of Indigenous peoples and state that "today, the nature of home, in urban Aboriginal spaces, located on former native homelands, is a dynamic process" (p.68). Their research includes interviews with 18 homeless young Aboriginal women who provided some valuable insights to the issue of homelessness for Aboriginal youth in urban Canada.

The analysis by Danika Overmars on the DSMIV is a 'must read' for anyone involved or interested in mental health and Indigenous peoples. Her article includes a comparative analysis of the DSM process and a Coast Salish naming ceremony where of course the outcomes are very different. Both processes involve that "a name is given to an individual by someone who occupies a position of respect and power" (p.82). Danika continues by explaining the differences however in particular how the names given under each circumstance has life long effects on those being named. She concludes with recommendations that are more culturally relevant than the labelling and resulting stigma that has traditionally been used in mental health services for Aboriginal peoples.

It is encouraging to read through an increase in the social sciences literature on matters related to Métis peoples and Dalene Thomas' article is no exception. By taking us through historical accounts of Metis life in Canada, she describes the issue of 'resistance' and survival for Metis families. Dalene also provides a synopsis of holistic living and values that can take the Métis child into a different era in Canada, surrounded by community love and reaching toward a greater freedom as one of Canada's lost children in child welfare.

The issue of adoption is close to my heart as many of you know. Reading Maria Bertsch and Bruce Bidgood's article on adoption practices framed in a First Nation ceremonial process was inspiring. The authors remind us that adoption sanctioned 'in a good way' can be a positive and life changing experience for Indigenous children and families. This article provides a welcomed change in adoption processes and hopefully will inspire others to follow the lead of the Lax Kwa'lam community members.

Children involved in child welfare experience a number of challenges in the school system. Keith Brownlee. Edward Rawana, Julia MacArthur and Michele Probizansky have approached this topic with helpful suggestions in how to ameliorate this experience. By encouraging a strong community/school relationship this authors suggest that the key to enhancing success for Aboriginal children in care is to utilize strengths' based assessment as the starting point. This is followed by building on the student's strengths to ensure that components of this are incorporated into their daily educational life. Experiences in giving back to the community and finally to participate in workshops or forums that can assist them deal with relevant issues that impact their lives such as grief is also part of this model which provides hope for other school jurisdictions who are looking for creative ways of addressing the school needs of children in care of child welfare services.

Steven Koptie calls us to be witnesses in the decolonization and resurgence of Indigenous ways of being. He states that "to be able to research, record and re-tell truths about unsustainable fallacies is to realize the eternal hope of survival that the Indigenous people continue to hold across Turtle Island (North America)." (p.123). this strong calling is for each of us 
First Peoples Child \& Family Review, Volume 5, Number 1, 2010

who are privileged with the opportunities need to remember our responsibilities toward other Indigenous peoples in our every day lives.

Elizabeth Fast and Collin Verzina provide us with a useful review of the literature on trauma and resilience for Indigenous peoples. This article offers some practical assistance to all those interested in these topics and immersed in the never ending search for relevant literature. Their conclusion that connection to culture and spirituality are the foundational supports for Indigenous people in the healing movement is actually not only a recommendation found in this article but seems to be the framework for each of the works inside the covers of this volume.

Finally Cathy Richardson's article on "Islands of Safety" leaves us with a lasting contribution from the voices, perspectives, knowledge and work of Métis Community Services in Victoria, B.C. Islands of Safety is a model and process designed to focus on dignity, resistance and safety knowledge for women and Indigenous peoples. This model, Islands of Safety, is based on rigorous safety planning, practices that dignify family members, and exploration of individuals' responses and resistance to violence in the family, negative social responses, and oppression that stems from colonial perspectives. Richardson's article reminds us that all human beings are spirited and that by preserving a person's dignity and integrity, we encompass the spiritual, physical, emotional and social needs of those individuals touched by violence.

I am pleased to have reviewed each of the articles within as I am a proud member of the editorial board for this journal. Again I am witness to how important this journal to our communities who are concerned with child and family services. In the last few years our circle has widened to a larger readership and scholarship which contributes to enduring realities that truly are multidisciplinary. The future of our journal continues to be bright as it offers insights into these important matters within an Indigenous paradigm.

\section{All my relations.}

Jeannine Carriere, Phd

Associate Professor

University of Victoria

School of Social Work 